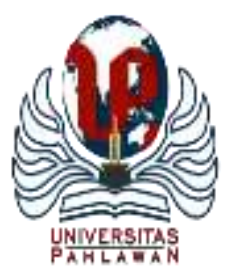

Edukatif : Jurnal Ilmu Pendidikan Volume 3 Nomor 6 Tahun 2021 Halm 3946 - 3953

EDUKATIF: JURNAL ILMU PENDIDIKAN

Research \& Learning in Education

https://edukatif.org/index.php/edukatif/index

\title{
Pengaruh Pengenalan Lapangan Persekolahan (PLP), Minat Mengajar, dan Prestasi Belajar terhadap Kesiapan Menjadi Guru bagi Mahasiswa Pendidikan Ekonomi
}

\author{
Harisma Khaerunnas ${ }^{1 凶}$, Mohamad Arief Rafsanjani \\ Universitas Negeri Surabaya, Indonesia ${ }^{1,2}$ \\ E-mail : $\underline{\text { harismakhae@gmail.com }}{ }^{1}$, mohamadrafsanjani@ unesa.ac.id ${ }^{2}$
}

\begin{abstract}
Abstrak
Penelitian ini bertujuan untuk mengetahui pengaruh pengenalan lapangan persekolahan (PLP), minat mengajar, dan prestasi belajar terhadap kesiapan menjadi guru bagi mahasiswa Prodi Pendidikan Ekonomi angkatan 2017 Unesa. Jenis penelitian yang digunakan adalah jenis penelitian eksplanasi dengan pendekatan kuantitatif. Adapun populasi penelitian ini adalah mahasiswa Prodi Pendidikan Ekonomi angkatan 2017 Unesa yang berjumlah 83 mahasiswa. Pengumpulan data menggunakan kuesioner dan IPK terakhir yang diperoleh dari Tata usaha (TU) Fakultas Ekonomi Unesa. Adapun teknik analisis data yang digunakan pada peneliatian ini menggunakan analisis regresi linier berganda. Hasil penelitian ini menunjukkan bahwa (1) Terdapat pengaruh positif signifikan pada variabel pengenalan lapangan persekolahan (PLP) terhadap kesiapan menjadi guru (2) Terdapat pengaruh positif signifikan pada variabel minat mengajar terhadap kesiapan menjadi guru, dan (3) Tidak Terdapat pengaruh positif signifikan pada variabel prestasi belajar terhadap kesiapan menjadi guru bagi mahasiswa prodi pendidikan ekonomi angkatan 2017 Unesa.
\end{abstract}

Kata Kunci: PLP, Minat Mengajar, Prestasi Belajar, Kesiapan Menjadi Guru

\section{Abstract}

This study aims to determine the effect of the introduction of the school field (PLP), interest in teaching, and learning achievement on readiness to become a teacher for students of the 2017 Unesa Economic Education Study Program. The type of research used is an explanatory research type with a quantitative approach. The population of this study were students of the 2017 Unesa economic education study program, totaling 83 students. Collecting data using a questionnaire and the latest GPA obtained from the Administration (TU) of the Faculty of Economics, Unesa. The data analysis technique used in this research uses multiple linear regression analysis. The results showed that (1) There was a significant positive effect on the variable introduction of the school field (PLP) on readiness to become a teacher (2) There was a significant positive effect on the variable of teaching interest on readiness to become a teacher, and (3) There was no significant positive effect on the variable learning achievement on readiness to become a teacher for students of the 2017 Unesa economic education study program.

Keywords: PLP, Teaching Interest, Learning Achievement, Readiness to Become a Teacher

Copyright (c) 2021 Harisma Khaerunnas, Mohamad Arief Rafsanjani

$\triangle$ Corresponding author:

Email : harismakhae@gmail.com

DOI : https://doi.org/10.31004/edukatif.v3i6.1353

ISSN 2656-8063 (Media Cetak)

ISSN 2656-8071 (Media Online)

Edukatif : Jurnal Ilmu Pendidikan Vol 3 No 6 Tahun 2021 p-ISSN 2656-8063 e-ISSN 2656-8071 
3947 Pengaruh Pengenalan Lapangan Persekolahan (PLP), Minat Mengajar, dan Prestasi Belajar terhadap Kesiapan Menjadi Guru bagi Mahasiswa Pendidikan Ekonomi - Harisma Khaerunnas, Mohamad Arief Rafsanjani

DOI: https://doi.org/10.31004/edukatif.v3i6.1353

\section{PENDAHULUAN}

Sumber daya yang berkualitas akan sangat menunjang dalam menentukan keberhasilan suatu Negara. Oleh sebab itu, peran guru disini perlu diperhatikan karena pendidikan yang lemah ditandai dengan rendahnya sumber daya manusia didalamnya. Untuk menghasilkan keberhasilan tersebut diperlukan calon guru yang mampu berperan dalam mempersiapkan proses pembelajaran yang efektif. Keberhasilan suatu pendidikan tidak lain bersumber dari guru yang memiliki kesiapan dan prestasi yang mampu menyalurkan ilmunya kepada peserta didik dan tentunya untuk mewujudkan hal tersebut sebagai seorang calon tenaga pendidik harus memiliki kompetensi yang baik (Darmadi, 2015). Kompetensi biasa dilihat dari segi kecakapan dalam pengetahuan, pengalaman, dan keterampilan yang baik agar mampu menjalankan tugasnya dalam membimbing, mengajar, mendidik, melatih, mengarahkan, mengevaluasi, dan menilai peserta didik dengan sebijak mungkin.

Pengenalan lapangan persekolahan (PLP) merupakan program wajib bagi mahasiswa yang mengambil jurusan pendidikan khusunya di Universitas Negeri Surabaya. Sebagai penunjang adanya program studi pendidikan, Universitas Negeri Surabaya telah bekerja sama dengan sekolah sebagai mitra dalam pelaksanaan pengenalan lapangan persekolahan (PLP). Pengenalan lapangan persekolahan (PLP) disini merupakan program wajib sekaligus mata kuliah yang harus diikuti oleh mahasiswa program studi kependidikan.

Pengenalan lapangan persekolahan (PLP) sendiri merupakan serangkaian kegiatan yang melibatkan mahasiswa untuk praktik mengajar langsung disekolah-sekolah yang telah ditentukan, dalam pelaksanaan lapangan persekolahan (PLP) mahasiswa berperan sebagai guru yang pada mata pelajaran yang telah disepakati dengan pihak sekolah tersebut sehingga mahasiswa mempersiapkan bahan ajar, mental, dan lainnya yang berkaitan dengan proses pembelajaran dikelas dengan sebaik mungkin. Karena pengenalan lapangan persekolahan (PLP) ini sifatnya wajib bagi calon guru sehingga mahasiswa yang akan melaksanakannya perlu mempersiapkan mental dan materil yang matang sehingga kedepannya bisa menjadi guru yang profesional. Disetiap mahasiswa pendidikan membutuhkan praktik keguruan yang saat ini dikemas dalam pengenalan lapangan persekolahan (PLP) untuk membentuk calon guru yang profesional dengan mempersiapkan mental dan materi yang sesuai dengan uji kompetensi (Mardiyono, 2012).

Pengenalan lapanga persekolahan (PLP) bertujuan untuk memperoleh pengalaman mengajar dan keterampilan mengajar yang baik untuk mendukung satu langkah lebih maju untuk menjadi tenaga pendidik yang profesional. Menurut Zainal (2015) dengan adanya PLP diharapkan dapat membentuk pribadi yang memiliki nilai sikap, pengetahuan, keterampilan, dan mental yang kuat. Sasaran dalam pengenalan lapangan persekolahan (PLP) adalah tercapainya kepribadian calon pendidik yang mempunyai pengetahuan dan keterampilan sebagai seorang guru yang dapat menggunakannya secara tepat dalam proses pengajaran baik di dalam maupun diluar lembaga pendidikan atau sekolah (Oemar, 2011).

Kegiatan wajib pengenalan lapangan persekolahan (PLP) ini diharapkan mampu menjadi landasan bagi mahasiswa untuk berlatih dan bereksplorasi dengan ilmu yang dibekali selama persiapan pelaksanaan kegiatan PLP dan berlatih mempersipakan diri untuk menjadi yang berkualitas dan tentunya dapat membimbing generasi bangsa menjadi lebih baik. Kesiapan untuk menjadi guru selain dipengaruhi oleh pengenalan lapangan Ppersekolahan (PLP) juga dipengaruhi oleh minat terhadap profesi tersebut.

Minat adalah suatu rasa ketertarikan pada suatu hal atau aktivitas secara suka rela (Slameto, 2010). Minat menjadi salah satu faktor penunjang kesiapan mahasiswa kependidikan untuk menjadi guru dimana minat juga merupakan suatu ketertarikan pada suatu hal atau aktivitas secara sukarela, minat yang ada dalam diri individu akan membuat individu lebih bersungguh-sungguh dalam mewujudkan impiannya, individu yang memiliki minat untuk menjadi guru masa depan akan lebih banyak menyiapkan diri untuk mewujudkan 
3948 Pengaruh Pengenalan Lapangan Persekolahan (PLP), Minat Mengajar, dan Prestasi Belajar terhadap Kesiapan Menjadi Guru bagi Mahasiswa Pendidikan Ekonomi - Harisma Khaerunnas, Mohamad Arief Rafsanjani

DOI: https://doi.org/10.31004/edukatif.v3i6.1353

impian tersebut dibandingkan dengan individu yang minatnya setengah-setengah atau bahkan tidak memiliki minat pada jurusan yang dia tempuh (Djaali, 2013).

Kesiapan untuk menjadi guru selain dipengaruhi oleh faktor-faktor diatas juga didukung oleh prestasi belajar mahasiswa, yang mana prestasi belajar tersebut dapat menunjang persiapan individu untuk menjadi tenaga pendidik yang profesional. Prestasi belajar adalah tindakan yang dimiliki peserta didik sebagai hasil dari proses belajar yang telah ditempuh meliputi semua hasil dari proses pembelajaran di sekolah atau di luar sekolah yang bersifat psikomotori, afektif, ataupun kognitif baik yang disengaja ataupun tidak (Sukmadinata, 2009). Tinggi rendahnya hasil belajar dikenal dengan istilah prestasi belajar. Prestasi belajar juga digunakan dalam menetapkan tingkat keberhasilan proses pembelajaran dan juga sebagai penentu taraf keberhasilan sebuah program pengajaran (Syah, 2010).

Berdasarkan penelitian terdahulu yang dilakukan oleh Sinaga (2014) belajar merupakan upaya yang dilakukan oleh individu guna mendapatkan suatu perubahan perilaku baru secara menyeluruh. Belajar dapat juga didevinisikan sebagai tahapan transformasi seluruh perilaku seseorang yang relatif tetap sebagai hasil pengalaman dan korelasi dengan lingkungan yang menyertakan proses kognitif (Syah, 2013). Sehingga prestasi belajar adalah keahlian nyata yang dapat diukur dengan keterampilan, sikap, dan pengetahuan sebagai jalinan aktif antar subyek dan obyek belajar selama proses pembelajaran berlangsung untuk menjangkau hasil belajar menggunakan Indeks Prestasi Komulatif (IPK). Prestasi belajar merupakan komponen penunjang keberhasilan seorang guru.

Penelitian ini merupakan penelitian eksplanasi dimana peneliti mengidentifikasi adanya pengaruh antar variabel. Dengan banyaknya peneltian yang membahas kesiapan menjadi guru, peneliti tertarik membahasa ke-3 variabel yang masing-masing memiliki peran untuk membentuk kesiapan untuk menjadi guru profesional. Dalam penelitian Simamora (2019) yang membahas "Pengaruh Minat Menjadi Guru dan Praktik Program Pengalaman Lapangan Terhadap Kesiapan Menjadi Guru Mahasiswa" hanya membahas variabel PLP, minat terhadap kesiapan sedangkan prestasi juga sangat perlu untuk menghasilkan kualitas calon guru. Dalam penelitian Yuniasari dan Djazari (2017) membahas "Pengaruh Minat Menjadi = Guru, Lingkungan Keluarga, dan Pengenalan Lapangan Persekolahan (PLP) Terhadap Kesiapan Menjadi Guru", juga hanya meneliti dua variabel bebas. sedangkan pada penelitian Junaidi et al (2018) meneliti "Pengaruh Lingkungan Keluarga, Prestasi Belajar, dan Motivasi Mahasiswa terhadap Kesiapan Menjadi Guru" yang hanya membahas prestasi belajar yang mana hasil penelitiannya menemukan bahwa prestasi belajar sangat memuaskan dalam kesiapan menjadi guru.

Berdasarkan fakta di lapangan bahwa proses pelaksanaan PLP sangat berbeda dari tahun sebelumnya calon guru dituntut untuk menyesuikan diri dengan kondisi yang tengah terjadi saat ini dan berdasarkan hasil evaluasi dari pamong masih banyaknya calon guru yang kurang percaya diri dalam mengajar, mengesampingkan persiapan untuk mengajar karena minatnya tidak untuk mengajar setelah tamat nanti serta kurangnya penguasaan terhadap kompetensi dalam pembelajaran yang mana itu juga berkaitan dengan prestasi belajar. Sehingga dengan segala pertimbanagn mengenai pentingnya variabel tersebut peneliti menggabungkan ke-3 variabel tersebut untuk mengetahui pengaruh dari variabel yang peneliti angkat.

Adapun tujuan pada penelitian ini untuk : (1) Untuk mengetahui pengaruh pengenalan lapangan persekolahan (PLP) terhadap kesiapan menjadi guru, (2) Untuk mengetahui pengaruh minat mengajar terhadap kesiapan menjadi guru, serta (3) Untuk mengetahui pengaruh prestasi belajar terhadap kesiapan menjadi guru.

Oleh karena itu, untuk memperjelas permasalahan yang telah diungkapkan maka dapat ditarik kesimpulan bahwa masalah dalam penelitian ini yaitu kesiapan untuk menjadi guru bagi Mahasiswa Prodi Pendidikan Ekonomi Angkatan 2017 Unesa dapat dibahas dengan tuntas sehingga dapat menghasilkan apa yang diharapkan, jadi dapat dilihat bahwa faktor yang mempengaruhi variabel tersebut yaitu Pengenalan 
3949 Pengaruh Pengenalan Lapangan Persekolahan (PLP), Minat Mengajar, dan Prestasi Belajar terhadap Kesiapan Menjadi Guru bagi Mahasiswa Pendidikan Ekonomi - Harisma Khaerunnas, Mohamad Arief Rafsanjani

DOI: https://doi.org/10.31004/edukatif.v3i6.1353

Lapangan Persekolahan (PLP), Minat Mengajar, dan Prestasi Belajar sebagai variabel manipulatif sedangkan Kesiapan Menjadi Guru sebagai variabel terikat.

\section{METODE PENELITIAN}

Penelitian ini merupakan penelitian eksplanasi dengan pendekatan kuantitatif. Populasi pada penelitian ini yaitu seluruh mahasiswa prodi pendidikan ekonomi angkatan 2017 dengan sampel sebanyak 83 responden. Pada penelitian ini menggunakan teknik sampling jenuh karena seluruh populasi diikut sertakan sebagai sampel dalam penelitian.

Teknik pengumpulan data pada penelitian ini menggunakan kuisioner dan dokumentasi. Kuisioner yang digunakan bersifat tertutup dan berskala likert untuk mengumpulkan data mengenai variabel yang diteliti. Adapun alternatif jawaban yang digunakan pada penelitian ini masing-masing memiliki skor yang berbeda, sedangkan teknik dokumentasi digunakan untuk mendapatkan data nilai IPK yang diperoleh dari Tata Usaha Prodi Pendidikan Ekonomi Unesa.

Indikator yang digunakan untuk mengukur setiap variabel yaitu: (1) Variabel pengenalan lapangan persekolahan (PLP) oleh Caires \& Almeida (2007) yang terdiri dari berpengalaman untuk bersosialisasi secara profesional dan kelembagaan, memiliki kompetensi untuk mengatur pengembangan pembelajaran, mengembangkan aspek sosio-emosional, dukungan sumber daya dan pengawasan, serta aspek kejuruan. (2) Variabel minat mengajar oleh Balyer \& Özcan (2014) yang terdiri dari merasa bahwa belajar itu berarti, merasa senang berinteraksi dengan peserta didik, suka membantu sesama, merasa tertantang untuk mengajar, menganggap profesi guru memiliki status sosial yang tinggi, menganggap profesi guru memiliki prospek karir yang baik, dan menganggap profesi guru lebih mudah menemukan pekerjaan. (3) Variabel kesiapan menjadi guru oleh Mohamed (2016) yang terdiri dari pengetahuan tentang kurikulum dan materi pembelajaran, perencanaan dan strategi instruksional, penggunaan bahan ajar dan teknologi efektif dalam memfasilitasi pembelajaran peserta didik, komitmen untuk mempromosikan pembelajaran kesemua peserta didik, mengelola peserta didik dan lingkungan belajar, pengetahuan tentang peserta didik yang beragam termasuk kebutuhan khusus dan cara mereka belajar, menyesuaikan pembelajaran untuk menanggapi kekuatan dan kebutuhan semua peserta didik, kolaborasi yang efektif dengan rekan kerja bermitra dengan orang tua layanan sosial maupun masyarakat, pertumbuhan dan pengembangan profesional, kesediaan untuk mencoba ide dan strategi baru, dan menjalankan integritas pribad dan tanggung jawab hukum.

Data hasil penelitaina ini akan diuji dengan teknik analisis linier berganda meliputi uji normalitas, uji lineraritas, dan uji hipotesis. Teknik analisis data menggunakan software SPSS

\section{HASIL DAN PEMBAHASAN PENELITIAN}

\section{Hasil Analisis Deskriptif}

Hasil analisis deskriptif pada variabel pengenalan lapangan persekolahan (PLP) dapat disimpulkan bahwa hasil yang diperoleh dari 83 responden sebesar 52,41\% responden yang memilih jawaban sangat setuju, pada variabel minat mengajar diperoleh $54,22 \%$ dari jumlah responden, sedanngkan pada variabel prestasi belajar yang dilihat dari nilai IPK terdapat $68,67 \%$ yang memiliki nilai dengan predikat cumlaude.

\section{Hasil Uji Prasyarat Analisis}

Uji prasyarat dalam penelitian ini yaitu uji normalitas, uji linieritas, dan uji hipotesis. Hasil uji normalitas menggunakan metode One-Sampel Kolmogorov-Sminov Test diperoleh nilai signifikan sebesar $0,200>0,05$ sehingga dikategorikan berdistribusi normal. Hasil uji linieritas menghasilkan nilai signifikan deviation from linearity sebesar 0,568 $>0,05$ sehingga diinterpretasikan antar variabel dependen dan variabel independen memiliki pengaruh linieritas. Hasil uji hipotesis nilai signifikan variabel penganalan lapangan persekolahan diperoleh $0,00<0,05$ dan variabel minat mengaj a diperoleh $0,022<0,05$ yang mana variabel 
3950 Pengaruh Pengenalan Lapangan Persekolahan (PLP), Minat Mengajar, dan Prestasi Belajar terhadap Kesiapan Menjadi Guru bagi Mahasiswa Pendidikan Ekonomi - Harisma Khaerunnas, Mohamad Arief Rafsanjani

DOI: https://doi.org/10.31004/edukatif.v3i6.1353

PLP dan minat dinyatakan memiliki pengaruh terhadap kesiapan menjadi guru. Sedangkan variabel prestasi belajar diperoleh nilai signifikan $0,118>0,05$ sehingga diinterprestasikan bahwa variabel tersebut tidak memiliki pengaruh terhadap kesiapan menjadi guru, dimana nilai prestasi belajar tidak berpengaruh terhadap minat mahasiswa untuk menjadi tenaga pendidik.

\section{Pembahasan}

\section{Pengaruh Pengenalan Lapangan Persekolah (PLP) Terhadap Kesiapan Menjadi Guru}

Dilihat dari hasil uji hipotesis pada variabel pengenalan lapangan persekolahan (PLP) terhadap kesiapan menjadi guru diperoleh nilai signifikan sebesar $0,00<0,05$ jadi dapat simpulkan bahwa kualitas praktik pengenalan lapangan persekolahan (PLP) berbanding lurus dengan kesiapan untuk menjadi guru. Adapun dilihat dari hasil analisis deskriptif diperoleh hasil 52,41\% sangat setuju, 41,22\% setuju, 5,59\% tidak setuju dan $0,6 \%$ sangat tidak setuju. Sehingga semakin tinggi kualitas praktik pengenalan lapangan maka kesiapan mahasiswa untuk menjadi guru semakin baik.

Praktik pengenalan lapangan persekolahan perlu diselenggarakan, harapannya dengan persiapan tersebut dapat mempersiapkan calon guru agar mudah dalam uji kompetensi guru Program pengenalan lapangan persekolahan (PLP) merupakan program studi wajib bagi mahasiswa keguruan yang mana syarat untuk melaksanakan program tersebut ialah mahasiswa harus lulus mata kuliah microteaching sehingga dipastikan bahwa sebelum terjun ke lapangan mahasiswa terlebih dahulu diberikan bekal kemampuan dalam pengetahuan dan keterampilan mengajar yang baik (Oemar, 2011). Dengan demikian adanya kegiatan wajib ini diharapkan mampu menjadi landasan bagi mahasiswa untuk berlatih dan mempersipkan diri menjadi guru yang berkualitas dan tentunya memiliki kompertensi profesional, sosial, kepribadian dan pedagogik sehingga dapat membimbing generasi untuk menjadi lebih baik (Slameto, 2010).

Hasil tersebut senada dengan hasil penelitian yang dilakukan oleh Firda (2021) dimana pada peneitian tersebut memiliki pengaruh positif signifikan antar variabel pengenalan lapangan persekolahan (PLP) terhadap kesiapan menjadi guru. Penelitian ini juga diperkuat dengan penelitian yang dilakukan oleh Baharuddin (2020) pengaruh positif signifikan sebesar 58,7\% serta penelitian yang dilakukan oleh Margunani (2018) yang memilki pengaruh positif signifikan sebesar $75,4 \%$ antar variabel pengenalan lapangan persekolahan (PLP) terhadap kesiapan menjadi guru.

Berdasarkan teori dan hasil penelitian terdahulu praktik pengenalan lapangan persekolahan sangat penting bagi mahasiswa pendidikan karena dengan adanya pengenalan lapangan persekolahan mahasiswa dapat memperoleh pengalaman, pengetahuan serta keterampilan dalam mengajar, hal tersebut berbanding lurus terhadap kesiapan mahasiswa untuk menjadi guru profesional.

\section{Pengaruh Minat Mengajar Terhadap Kesiapan Menjadi Guru}

Berdasarkan hasil uji hipotesis pada variabel minat mengajar terhadap variabel kesiapan menjadi guru diperoleh nilai signifikan sebesar 0,02 $<0,05$ dimana dapat diinterpretasikan bahwa semakin besar minat mahasiswa maka semakin besar pula kesiapannya untuk menjadi guru begitupun sebaliknya.

Adapun hasil analisis deskriptif diperoleh sebesar 50,6\% mahasiswa yang memilih sangat setuju, $42,17 \%$ memilih setuju, 6,02\% memilih tidak setuju, dan 1,2\% memilih sangat tidak setuju. Hal tersebut terlihat sangat jelas bahwa lebih dari 50\% mahasiswa memiliki minat dalam mengajar dan tentunya sangat berpengaruh terhasap kesiapan untuk menjadi guru.

Minat merupakan suatu ketertarikan pada aktivitas atau kegiatan tanpa adanya rasa terpaksa akan hal tersebut, semakin kuat minat individu maka semakin kuat pula dorongan terhadap keinginan untuk mencapainya. Minat menjadi salah satu faktor pendukung individu untuk mewujudkan keinginannya sehingga dengan adanya minat dalam diri individu dapat meningkatkan kemauan bahkan kesiapan dalam mewujudkan 
3951 Pengaruh Pengenalan Lapangan Persekolahan (PLP), Minat Mengajar, dan Prestasi Belajar terhadap Kesiapan Menjadi Guru bagi Mahasiswa Pendidikan Ekonomi - Harisma Khaerunnas, Mohamad Arief Rafsanjani

DOI: https://doi.org/10.31004/edukatif.v3i6.1353

impiannya untuk menjadi tenaga pendidik. Minat yang kuat dalam diri individu menjadikanya lebih bersungguh-sungguh dalam menyiapkan diri menjadi guru profesional (Djaali, 2013).

Hasil tersebut diperkuat dengan penelitian yang dilakukan Yuniasari \& Djazari (2017) menunjukkan adanya pengaruh positif signifikan antar minat mengajar terhadap kesiapan menjadi guru. Peneitian ini juga didukung dalam penelitian Marzukoh (2020) terdapat pengaruh positif signifikan sebesar 35\% serta penelitian yang dilakukan oleh Ulin \& Oktarina (2014) terdapat pengaruh positif signifikan sebesar $72.8 \%$ pada variabel minat mengajar terhadap kesiapan menjadi guru.

Berdasarkan uraian diatas menunjukkan bahwa dengan adanya minat yang kuat bagi setiap individu dapat menunjang kesiapan untuk menjadi guru profesional, adapun faktor yang pendukung minat disini dilihat dari faktor intrinsik yang bersumber dari dalam diri individu yang cenderung terhadap sesuatu yang diinginkan dan faktor ekstrinsik yang bersumber dari luar berupa dorongan orang terdekat seperti orang tua. Hal itu senada dengan teori dan hasil peneliti terdahulu dimana besarnya minat atau keinginan yang ada dalam diri individu dapat menjadikannya sebagai motivasi untuk mempersiapkan diri demi mewujudkan apa yang diinginkan seperti menjadi tenaga pendidik yang profesional.

\section{Pengaruh Prestasi Belajar Terhadap Kesiapan Menjadi Guru}

Berdasarkan hasil penelitian ini ditunjukkan bahwa hasil yang diperoleh dalam uji hipotesis variabel prestasi belajar sebesar $0,118>0,05$ pada taraf signifikan 5\% yang mana hasil tersebut dinyatakan ditolak, hal tersebut menunjukkan bahwa tidak adanya pengaruh antar variabel prestasi belajar terhadap kesiapan menjadi guru.

Demikian jika dilihat dari hasil analisis deskriptif diperoleh skor tertinggi 68,67\% predikat prestasi belajar dengan pujian atau memiliki nilai sangat memuaskan, dilanjutkan skor 30,12\% predikat prestasi belajar memuaskan dan skor 1,2\% dengan predikat prestasi belajar cukup. Diketahui bahwa tingginya prestasi yang dimiliki inidividu dapat menunjang keberhasilan proses pembelajaran karena dapat dikatakan bahwa individu tersebut lebih siap untuk menyalurkan ilmu kedepannya, hal ini juga tergolong dalam beberapa faktor yang dapat menambah wawasan atau pengalaman individu, keterampilan individu, dan juga pengetahuan individu itu sendiri (Agusti, 2020).

Hasil penelitian menunjukkan rata-rata prestasi belajar yang dimiliki oleh mahasiswa yang menajadi responden mayoritas memiliki predikat prestasi yang sangat tinggi namun jika dilihat dari hasil uji hipotesis pada penelitian ini tidak termasuk dalam salah satu variabel yang mendukung kesiapan mahasiswa untuk menjadi guru.

Berdasarkan teori dan hasil penelitian terdahulu variabel prestasi belajar merupakan salah satu variabel yang banyak digunakan sebagai bentuk penilaian keberhasilan suatu pendidikan. Tingginya prestasi belajar pada individu tentunya sangat membantu dalam mengimplementasikan ilmu kedepannya. Menurut penelitian yang dilakukan oleh Olivia (2018) adanya pengaruh positif signifikan antar variabel prestasi belajar terhadap kesiapan menjadi guru. Namun pada penelitian ini variabel prestasi belajar tidak memiliki pengaruh signifikan dan tidak menjadi salah satu faktor penentu kesiapan bagi mahasiswa untuk menjadi guru. Penelitian ini diperkuat dengan penelitian yang dilakukan oleh Mardiah \& Yulhendri (2020) yang menjelaskan bahwa tidak adanya pengaruh signifikan antara prestasi belajar terhadap kesiapan menjadi guru mesipun prestasi belajar mahasiswa Pendidikan Ekonomi tinggi.

\section{KESIMPULAN}

Berdasarkan hasil penelitian mengenai pengenalan lapangan persekolahan (PLP), minat mengajar, dan prestasi belajar terhadap kesiapan menjadi guru mahasiswa prodi pendidikan ekonomi angkatan 2017 Unesa maka dapat ditarik simpulan bahwa terdapat pengaruh positif signifikan pada variabel pengenalan lapangan persekolahan (PLP) serta variabel minat mengajar terhadap kesiapan menjadi guru mahasiswa prodi 
3952 Pengaruh Pengenalan Lapangan Persekolahan (PLP), Minat Mengajar, dan Prestasi Belajar terhadap Kesiapan Menjadi Guru bagi Mahasiswa Pendidikan Ekonomi - Harisma Khaerunnas, Mohamad Arief Rafsanjani

DOI: https://doi.org/10.31004/edukatif.v3i6.1353

pendidikan ekonomi angkatan 2017 Unesa. Sedangkan pada variabel prestasi belajar terhadap kesiapan menjadi guru mahasiswa prodi pendidikan ekonomi angkatan 2017 Unesa tidak memiliki pengaruh positif signifikan.

\section{DAFTAR PUSTAKA}

Agusti, I. S. (2020). Pengaruh Efikasi Diri dan Prestasi Akademik terhadap Kesiapan Menjadi Guru Mahasiswa Stambuk 2016 Pendidikan Bisnis Fakultas Ekonomi Universitas Negeri Medan. Niagawan, 9(1), 65. https://doi.org/10.24114/niaga.v9i1.17657

Baharuddin, F. R., Palerangi, A. M., Kunci, K., \& Profesional, G. (2020). Pinisi : Journal of Teacher Professional Artikel info Artikel history: Received ; 7-03-2020 Revised : 19-03-2020 Accepted ; 28-042020. 1, 54-66.

Balyer, A., \& Özcan, K. (2014). Choosing Teaching Profession as a Career : Students 'Reasons. 7(5), 104115. https://doi.org/10.5539/ies.v7n5p104

Caires, S., \& Almeida, L. S. (2007). Journal of Education for Teaching : International research and pedagogy Teaching practice in Initial Teacher Education : its impact on student teachers 'professional skills and development. November 2014, 37-41. https://doi.org/10.1080/02607470500127236

Darmadi, H. (2015). Tugas, Peran, Kompetensi, dan Tanggung Jawab Menjadi Guru Profesional. Jurnal Edukasia.

Djaali. (2013). Psikologi Pendidikan (p. 121). PT. Bumi Aksara.

Firda, I. (2021). Pengaru Pengenalan LApangan Persekolahan (PLP) dan Minat Mengajar Terhadap Kesiapan Menjadi Guru Pada Mahasiswa FKIP Pendidikan Ekonomi Angkatan 2016 Universitas Jambi. Doctoral Deissertation, Universitass Jambi.

Junaidi, N., Silvia, A., \& Susanti, D. (2018). Pengaruh Motivasi Memasuki Dunia Kerja dan Prestasi Belajar terhadap Kesiapan Kerja Mahasiswa Jurusan Pendidikan Ekonomi Fakultas Ekonomi Universitas Negeri Padang. Jurnal Ecogen, 1(2), 408. https://doi.org/10.24036/jmpe.v1i2.4762

Mardiah, \& Yulhendri. (2020). Pengaruh IPK, Micro Teaching, dan Praktik Pengalaman Lapangan (PPL) terhadap Kompetensi Pedagogik Mahasiswa Calon Guru Jurusan Pendidikan Ekonomi FE UNP. Eko Gen, 3(1), 165-175.

Mardiyono. (2012). Menjadi Guru Yang Profesional (M. Usman (ed.)). Remaja Rosdakarya.

Margunani, B. R. (2018). Pengaruh Minat Menjadi Guru, Penguasaan MKDK, dan PPL terhadap Kesiapan Mahasiswa Menjadi Guru. Economic Education Analysis Journal, 7(1), 59-74.

Marzukoh, T. (2020). Pengaruh Minat Belajar Terhadap Kesiapan Menjadi Guru Profesional Mahasiswa Pendidikan Guru Madrasah Ibtidaiyah Angkatan 2016 Universitas Islam Malang.

Mohamed, Z., Valcke, M., \& Wever, B. De. (2016). Can mastery of Teacher Competences Determine Student Teachers 'Readiness for the Job?

Oemar, H. (2011). Proses Belajar Mengajar (pp. 171-172). PT. Bumi Aksara.

Olivia, M. (2018). Pengaruh Minat Menjadi Guru, Peran Guru Pamong , Prestasi Belajar dan Praktik Pengalaman Lapangan Terhadap Kesiapan Mahasiswa Pendidikan Ekonomi STKIP PGRI Sumatera Barat Menjadi Guru Profesional.

Simamora, E. H. (2019). Pengaruh Minat Menjadi Guru dan Praktik Program Pengalaman Lapangan Terhadap Kesiapan Menjadi Guru Mahasiswa Angkatan 2015 FKIP-Ekonomi Universitas HKBP Nommensen Medan. 105(3), 129-133.

https://webcache.googleusercontent.com/search?q=cache:BDsuQOHoCi4J:https://media.neliti.com/med ia/publications/9138-ID-perlindungan-hukum-terhadap-anak-dari-konten-berbahaya-dalam-media- 
3953 Pengaruh Pengenalan Lapangan Persekolahan (PLP), Minat Mengajar, dan Prestasi Belajar terhadap Kesiapan Menjadi Guru bagi Mahasiswa Pendidikan Ekonomi - Harisma Khaerunnas, Mohamad Arief Rafsanjani

DOI: https://doi.org/10.31004/edukatif.v3i6.1353

cetak-dan-ele.pdf $+\& c d=3 \& h l=i d \& c t=c l n k \& g l=i d$

Sinaga, S. O. (2014). Pengaruh Sosial Ekonomi Orang Tua dan Prestasi Belajar Siswa Pada Mata Pelajaran Ekonomi Terhadap Minat Anak Melanjutkan Pendidikan Ke Perguruan Tinggi di Kelas XI IPS SMA Swasta Raksana Medan Tahun Ajaran 2013/2014.

Slameto. (2010). Belajar dan Faktor-faktor yang Mempengaruhi. Rineka Cipta.

Sukmadinata, N. S. (2009). Landasan Psikologi Proses Pendidikan (p. 124). PT Remaja Rosdakarya.

Syah, M. (2010). Psikologi Pendidikan dengan Pendekatan Baru (p. 100). Remaja Rosdakary.

Syah, M. (2013). Psikologi Pendidikan dengan Pendidikan Baru (p. 257). PT. Remaja Rosda Karya.

Ulin, F., \& Oktarina, N. (2014). Pengaruh Minat Profesi Guru, Locus of Control Internal, Peran Guru Pamong Dan Prestasi Belajar Terhadap Kesiapan Mahasiswa Menjadi Guru Pada Jurusan Pendidikan Ekonomi Fakultas Ekonomi Universitas Negeri Semarang. Economic Education Analysis Journal, 3(2), 336-342.

Yuniasari, T., \& Djazari, M. (2017). Pengaruh Minat Menjadi Guru, Lingkungan Keluarga, dan Praktik Pengalaman Lapangan (PPL) terhadap Kesiapan Menjadi Guru Akuntansi Mahasiswa Pendidikan Akuntansi Angkatan 2013 FE UNY. Jurnal Pendidikan Akuntansi Indonesia, 15(2). https://doi.org/10.21831/jpai.v15i2.17220

Zainal, A. (2015). Micro Teaching disertai dengan Pedoman Pengalaman Lapangan. PT Raja Grafindo Persada. 